\title{
Clinical and Economic Results of Ventriculoperitoneal Shunt Infections in Children
}

\author{
Çocuklarda Ventriküloperitoneal Şant Enfeksiyonlarmun Klinik ve \\ Ekonomik Sonuçlart
}

Ali KANIK, Seda SIRIN, Engin KOSE, Kayı ELIACIK, Murat ANIL, Mehmet HELVACI

Tepecik Education and Research Hospital, Department of Pediatrics, Izmir, Turkey

Corresponding Author: Ali KANIK / E-mail: dralikanik@hotmail.com

\begin{abstract}
AIM: This study evaluated the clinical and economic outcomes of ventriculoperitoneal shunt infections.

MATERIAL and METHODS: Patients diagnosed with ventriculoperitoneal shunt infections for the first time between 1 January 2007 and 31 December 2011 were included in this study. Demographic, clinical, and economic data were analyzed retrospectively. A cost coefficient (total cost/follow-up period) and hospitalization coefficient (duration of hospitalization/follow-up period) were calculated for each patient.

RESULTS: In total, 132 shunt infections (mean follow-up, $734 \pm 367$ days) were evaluated in 51 patients (mean age, $16.6 \pm 9.22$ months; median age, 3 months; range, 1-88 months; 28 females, 21 males). In 23 patients (45\%), shunt infections were seen in the first 2 months following shunt placement. Seven patients died during the follow-up. There was a negative correlation between the age at diagnosis and the hospitalization duration $(p=0.005, r=-0.381)$. The average cost of hospitalization per patient was $6397 \pm 4338 \mathrm{TL}$. There was a negative correlation between the cost index and the age at diagnosis $(p=0.04, r=-0.292)$.
\end{abstract}

CONCLUSION: Ventriculoperitoneal shunt infections have significant medical and economic impacts. Younger the diagnosis of patients, the hospitalization duration and treatment cost were higher.

KEYWORDS: Child, Cost, Infection, Morbidity, Ventriculoperitoneal shunt

öz

AMAÇ: Ventriküloperitoneal şant enfeksiyonu geçiren çocukların klinik ve ekonomik sonuçlarının değerlendirilmesi amaçlandı

YÖNTEM ve GEREÇLER: Çalışmaya 1 Ocak 2007 ile 31 Aralık 2011 tarihleri arasında ilk kez ventriküloperitoneal şant enfeksiyonu tanısı alan olgular alındı. Hastaların demografik ve klinik özellikleri ile enfeksiyonun maliyeti değerlendirildi. Her bir hasta için maliyet (toplam maliyet / izlem süresi) ve yatış süresi (hastanede yatış süresi / izlem süresi) katsayıları hesaplandı.

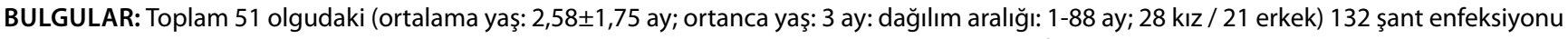
(ortalama izlem süresi: 734 367 gün) değerlendirilmeye alındı. Olguların 23'ünde (\%45) ilk enfeksiyon şantın takılmasından sonraki ilk 2 ayda ortaya çıktı. Toplam yedi hasta izlemde kaybedildi. Olguların tanı yaşları ile yatış süresi katsayıları arasında negatif yönde anlamlı bir korelasyon olduğu görüldü $(p=0,005 ; r=-0,381)$. Bir hasta için yatış başına düşen ortalama maliyet $6397 \pm 4338$ TL olarak hesaplandı. Bu hastaların maliyet katsayısı ile tanı yaşı arasında negatif yönde anlamlı bir korelasyon saptandı $(p=0,04 ; r=-0,292)$.

SONUÇ: Ventriküloperitoneal şant enfeksiyonları ciddi tıbbi ve ekonomik sonuçlara neden olmaktadır. Hastaların tanı yaşı küçüldükçe hastanede yatış süreleri ve tedavi maliyetleri artmaktadır.

ANAHTAR SÖZCÜKLER: Çocuk, Maliyet, Enfeksiyon, Morbidite, Ventriküloperitoneal şant

\section{INTRODUCTION}

Shunt infections have become a major problem in the treatment of hydrocephalus since the development of ventriculoperitoneal shunt (VPS) systems. The incidence of cerebrospinal fluid (CSF) shunt infections varies from $5 \%$ to $41 \%(15)$. The prevalence of shunt infections has decreased to $10 \%$ in recent years as a result of new developments $(1,3)$. Improper treatment of shunt infections results in serious morbidity, mortality, high treatment costs, and psychosocial distress (11). The risk of infection is affected by factors including patient age, immunologic status, factors associated with the surgery and surgeon, materials used, surgical technique, and the number of previous shunt surgeries (5).

Few scientific reports covering VPS infections (VPSI) have been published in Turkey because of the insufficient number of scientific studies performed in this country. This study evaluated both the medical and economic outcomes of VPSI in children $(5,13,23)$.

\section{MATERIAL and METHODS}

This retrospective study evaluated patients who were diagnosed with VPSI and hospitalized at the Clinic of Pediatric 
Infectious Diseases of Izmir Tepecik Training and Research Hospital between 1 January 2007 and 31 December 2011. Fifty-one children diagnosed with VPSI for the first time were included in this case study. The exclusion criteria were VPSI before the study period, a history of a shunt operation in another center, and a lack of medical records. The criteria for a diagnosis of CSF shunt infection were as follows: a positive CSF culture, CSF findings consistent with infection (leukocyte count of $>50 / \mathrm{mm}^{3}$ or glucose ratio [CSF glucose/serum glucose] of $<0.4$ ) associated with fever [temperature of $\left.>38.5^{\circ} \mathrm{C}\right]$ ), shunt malfunction, or neurological symptoms (17, 20, 27). Burr-hole type shunts were placed in all patients with medium pressure adjustment $\left(70-110 \mathrm{mmH}_{2} \mathrm{O}\right)$, and cefazolin sodium prophylaxis was intravenously administered before the skin incision $(25 \mathrm{mg} / \mathrm{kg})$; two doses were repeated within $24 \mathrm{~h}$ after the surgery $(12,21)$. The patients were divided into four groups according to the time at which VPSI first developed: 0 to 2 months, 2 to 6 months, 6 to 12 months, and 12 months after the surgery. In addition, patients with a first VPSI were divided into two groups: those hospitalized for more or less than 21 days. Clinical and laboratory findings affecting the duration of hospitalization were investigated. One of two VPSI management protocols was chosen according to the preference of the neurosurgeon and pediatrician. The first method involved removal of the infected shunt, placement of an external ventricular drain, and administration of empirical antibiotic therapy. The second method involved treatment with antibiotic therapy without surgical intervention. Treatment without external ventricular drainage was performed at the preference of the neurosurgeon. The treatment duration was determined by the clinical condition, type of microorganism, and CSF findings. The cost per patient, including the bed, antibiotic, laboratory, radiological, and surgical cost, was evaluated based on that year's price list drafted by the Turkish Ministry of Health. The total cost and total duration of hospitalization were affected by the length of the follow-up period. The effect of the length of the follow-up period was mathematically adjusted to more accurately determine the effects of factors such as patient age, age at first infection, and premature birth. The concepts of the coefficient of cost and the coefficient of hospitalization were developed as a result. The coefficient of cost (total cost/follow-up period) and the coefficient of hospitalization (length of hospital stay/follow-up period) were estimated for all patients, and the relationships between these coefficients and risk factors were investigated. This study was approved by our institution's Ethics Committee (06.04.2011-15/9).

Statistical evaluation was performed with the Statistical Package for the Social Sciences, version 18.0 (SPSS V18.0) Numerical data and arithmetic means \pm standard deviation are expressed as median, minimum, and maximum values. Categorical data are expressed as points ( $n$ ) and percentages (\%). The chi-square test and Fisher's exact test were used to compare proportional data, and the Mann-Whitney $U$ test was used to compare the binary groups. Spearman's correlation analysis was conducted for numerical analysis of the data affecting the hospitalization coefficient. A $p$ value of $<0.05$ was considered to indicate statistical significance.

\section{RESULTS}

The age range of the study group was 1 to 88 months (mean age, $16.6 \pm 9.22$ months; median age, 3 months); 28 of the 51 patients were female (55\%). The mean follow-up period was $20.6 \pm 1.5$ months (median, 21.3 months; minimum, 1.7 months; maximum, 53.8 months), and all patients were hospitalized a total of 132 times due to VPSI. During the study period, 835 shunt operations were performed by the Neurosurgery Department; 495 (59\%) were de novo shunts, and 340 (41\%) were revisions for shunt surgery. A shunt infection rate of $15.8 \%(n=132)$ was observed during the follow-up period. Shunt infection recurred in 33 (64\%) patients. Seventeen patients $(29 \%)$ had a history of premature birth, and 42 patients (83\%) were $<1$ year old. The etiology of hydrocephalus was congenital malformation (meningomyelocele, Dandy-Walker malformation, etc.) in 30 of 51 patients (58.8\%), infection in 4 patients $(7.8 \%)$, intraventricular hemorrhage due to prematurity in 8 patients (15.7\%), and an intracranial space-occupying entity in 3 patients $(5.9 \%)$. The etiology could not be identified in six patients (11.8\%). After shunt placement, infections occurred in 23 patients (45\%) in the first 2 months, in 12 patients (23\%) at 2 to 6 months, in 7 patients (13\%) at 6 to 12 months, and in 9 patients (17\%) after month 12.

The mean hospitalization duration was $26.3 \pm 22.5$ days during the first VPSI. Thirty-three of all patients (64.7\%) stayed less than 21 days, while 18 (35.3\%) stayed for more than 21 days. Hospitalization lasted more than 21 days for patients with a history of premature birth and with a lower CSF/blood glucose ratio ( $p=0.017$ and 0.006 , respectively). In 37 patients, the shunt was removed and external ventricular drainage was applied; 14 patients (28\%) were treated with only antibiotics (no shunt removal). The duration of hospitalization did not differ between these two groups ( $p=0.487$ ) (Table I). The mean number of hospitalized patients was $2.58 \pm$ 1.75 (median, 2; range, 1-7), and the mean hospitalization coefficient (length of hospital stay/follow-up period) was $0.17 \pm 0.22$. The hospitalization coefficient was higher in patients with a history of premature birth and who developed their first shunt infection before the first 3 months of age $(p=$ 0.002 and 0.001, respectively) (Table II). Similarly, a negative correlation was found between the age at diagnosis and the hospitalization coefficient ( $p=0.005, r=-0.38$ ) (Figure 1).

Positive CSF cultures were identified in 25 patients (49\%) (gram-positive bacteria, 13 [52\%]; gram-negative bacteria, 11 [44\%]; fungal, 1 [4\%]). Seven patients (13.7\%) (four females) died during the follow-up period. The cause of death was septic shock in three patients, cerebral herniation in three, and respiratory failure in one.

The average cost of hospitalization was $6397 \pm 4338 \mathrm{TL}$ (median, 5397; range, 2003-17,160). This amount included the antibiotic, laboratory, radiology, surgery, and bed costs. 
During this time, the total cost per patient divided by the number of patients was estimated to be $16,188 \pm 11,195$ $\mathrm{TL}$ (median, 12,987; range, 5102-44,272). The mean cost coefficient (total cost/follow-up period) was $43.0 \pm 65.5 \mathrm{TL} /$ day, and a moderate negative correlation with patient age was noted ( $p=0.04, r=-0.29$ ) (Figure 2). Considering the relationships between the cost coefficient and various factors, a statistically significant difference was found between shunt infections at an early age and prematurity $(p=0.06$ and 0.005 , respectively) (Table II).

\section{DISCUSSION}

Cerebrospinal shunts play a key role in the management of hydrocephalus. However, many complications are associated with shunt application. The most common complication is shunt infection. Shunt-related deaths account for onethird of all deaths due to shunt infection (20). This study evaluated the medical and economic aspects of VPS-related infections in children at our hospital. Although there are many similar international reports, there are a limited number of such studies in Turkey. Risk factors affecting the duration of hospitalization and patient costs were analyzed. In this analysis, the hospitalization duration and cost coefficient were used to minimize the effects of the follow-up duration on the cost and number of hospitalizations. The literature reports that the prevalence of VPSI is $10 \%$ and that it most commonly

Table I: Parameters Related to the Duration of Hospitalization

\begin{tabular}{|c|c|c|c|c|}
\hline Parameters & & $\begin{array}{l}\text { Hospitalization duration } \\
\qquad \begin{array}{c}<21 \text { days } \\
n=33(\%)\end{array}\end{array}$ & $\begin{array}{l}\text { Hospitalization duration } \\
\qquad \begin{array}{c}>21 \text { days } \\
n=18(\%)\end{array}\end{array}$ & $\mathbf{p}$ \\
\hline Age (month), median & & 3 & 2 & 0.500 \\
\hline Gender, n (\%) & $\begin{array}{l}\text { Male } \\
\text { Female }\end{array}$ & $\begin{array}{l}19(57.5) \\
14(42.5)\end{array}$ & $\begin{array}{l}9(50 \%) \\
9(50)\end{array}$ & 0.600 \\
\hline $\begin{array}{l}\text { CSF culture, } \\
\mathrm{n}(\%)\end{array}$ & $\begin{array}{l}(+) \\
(-) \\
\text { Gram positive } \\
\text { Gram negative }\end{array}$ & $\begin{array}{l}15(60) \\
18(56.2) \\
10(66.6) \\
5(33.4)\end{array}$ & $\begin{array}{l}10(40) \\
9(50) \\
3(33.4) \\
6(66.6)\end{array}$ & $\begin{array}{l}0.600 \\
0.262 \\
0.301\end{array}$ \\
\hline Birth, n (\%) & $\begin{array}{l}\text { Term } \\
\text { Preterm }\end{array}$ & $\begin{array}{r}27(81) \\
6(19)\end{array}$ & $\begin{array}{l}9(50) \\
9(50)\end{array}$ & 0.017 \\
\hline CSF /Blood glucose, median & & 0.4 & 0.3 & 0.006 \\
\hline CSF protein gr/dl, median & & 138 & 240 & 0.250 \\
\hline CSF leukocyte $/ \mathrm{mm}^{3}$, median & & 80 & 85 & 0.493 \\
\hline \multirow{2}{*}{ The etiology of hydrocephalus, n (\%) } & Congenital & $23(69.6)$ & $12(66.6)$ & \multirow{2}{*}{0.412} \\
\hline & Acquired & $10(31.4)$ & $6(33.4)$ & \\
\hline EVD n (\%) & $(+)$ & $25(75.7)$ & $12(66.6)$ & 0.487 \\
\hline
\end{tabular}

CSF: cerebrospinal fluid, EVD: external ventricular drainage.

Table II: Relationships of Coefficient of Hospitalization and Coefficient of Cost with Various Factors

\begin{tabular}{|c|c|c|c|c|c|c|}
\hline Parameters & & & $\begin{array}{l}\text { Coefficient of } \\
\text { hospitalization }\end{array}$ & $\mathbf{p}$ & $\begin{array}{c}\text { Coefficient of } \\
\text { cost }\end{array}$ & $\mathbf{p}$ \\
\hline Gender & $\begin{array}{l}\text { Female } \\
\text { Male }\end{array}$ & $\begin{array}{l}n: 28 \\
n: 23\end{array}$ & $\begin{array}{l}0.15 \\
0.11\end{array}$ & 0.7 & $38.1 \pm 74.4$ & 0.6 \\
\hline First Shunt infection age & $\begin{array}{l}<3 \text { months } \\
>3 \text { months }\end{array}$ & $\begin{array}{l}n: 28 \\
n: 23\end{array}$ & $\begin{array}{l}0.11 \\
0.04\end{array}$ & 0.002 & $\begin{array}{l}57.8 \pm 80.0 \\
24.9 \pm 35.5\end{array}$ & 0.006 \\
\hline Etiology of hydrocephalus & $\begin{array}{l}\text { Congenital } \\
\text { Acquired }\end{array}$ & $\begin{array}{l}n: 35 \\
n: 16\end{array}$ & $\begin{array}{l}0.10 \\
0.09\end{array}$ & 0.413 & $\begin{array}{l}48.0 \pm 72.2 \\
30.3 \pm 46.2\end{array}$ & 0.401 \\
\hline Birth & $\begin{array}{l}\text { Term } \\
\text { Preterm }\end{array}$ & $\begin{array}{l}\mathrm{n}: 36 \\
\mathrm{n}: 15\end{array}$ & $\begin{array}{l}0.06 \\
0.15\end{array}$ & 0.001 & $\begin{array}{l}30.9 \pm 42.8 \\
71.9 \pm 97.2\end{array}$ & 0.005 \\
\hline EVD & $\begin{array}{l}(+) \\
(-)\end{array}$ & $\begin{array}{l}n: 37 \\
n: 14\end{array}$ & $\begin{array}{l}0.10 \\
0.08\end{array}$ & 0.941 & $\begin{array}{l}47.5 \pm 72.2 \\
31.1 \pm 42.8\end{array}$ & 0.479 \\
\hline
\end{tabular}

EVD: external ventricular drainage. 


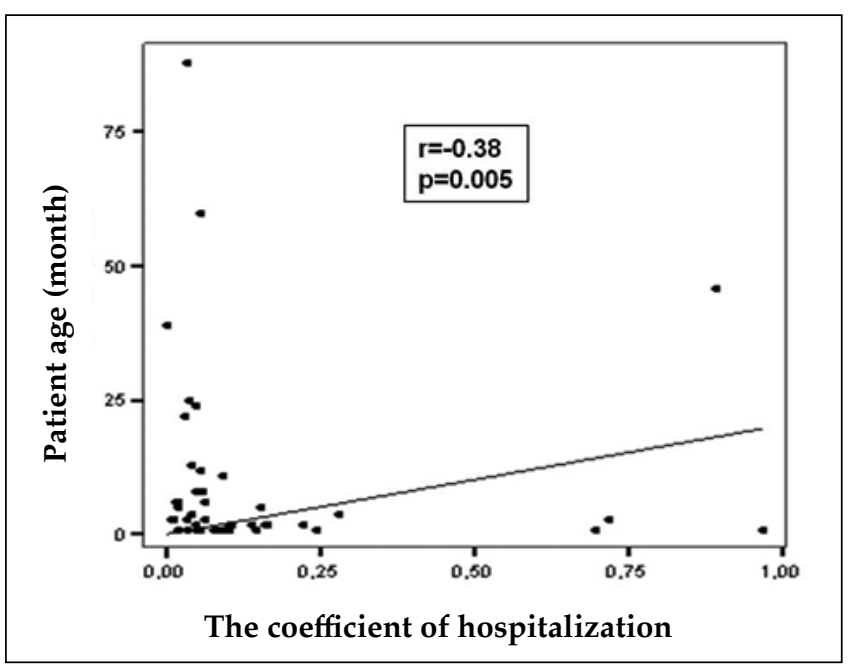

Figure 1: Correlation analysis between patient age and coefficient of hospitalization.

occurs in the first 2 months postoperatively. The prevalence of VPSI is reportedly $16 \%$ in Turkey. Mortality rates due to shunt infection vary from $10 \%$ to $13 \%(1,6-9,13,18,19,25,26)$. This study found a VPSI prevalence of $15.8 \%$, which is higher than the values reported in the literature. Etiological factors, younger age, and nonuse of antibiotic-impregnated shunts were among the factors that affected our findings. Consistent with the literature, infections were most commonly observed in the first 2 months postoperatively. Thirteen percent of shunted patients died during the follow-up period.

A low glucose level in the CSF indicates greater bacterial disease severity in the central nervous system. A low CSF/ serum glucose ratio in patients with VPSI also affects the duration of hospitalization $(22,23)$. This study found that the CSF/glucose ratio was lower in patients hospitalized for more than 3 weeks.

Factors including premature birth, occurrence of the first VPSI at a young age, congenital conditions such as meningomyelocele, post-hemorrhagic hydrocephalus, higher number of previous shunt infections, and the development of postoperative CSF leakage increase the risk of shunt infection $(4,6,7,18,25)$. In this study, we found that children with VPSI in the first 3 months or with premature birth had a greater rate of shunt infections (high hospitalization coefficient) and higher treatment costs (high cost coefficient). The etiologies of hydrocephalus among the patients could not be divided into many separate groups because of the small sample size; therefore, the etiologies were divided into only two groups: congenital and acquired. In this study, we found that the etiology of hydrocephalus and sex did not affect the hospitalization coefficient.

Shunt infections are caused by previous CSF infections or occur more generally due to skin contamination during surgical procedures $(4,14)$. The surgeon's ability, speed, and experience; the timing of surgery; and the operating room conditions are controversial subjects in terms of the risk of

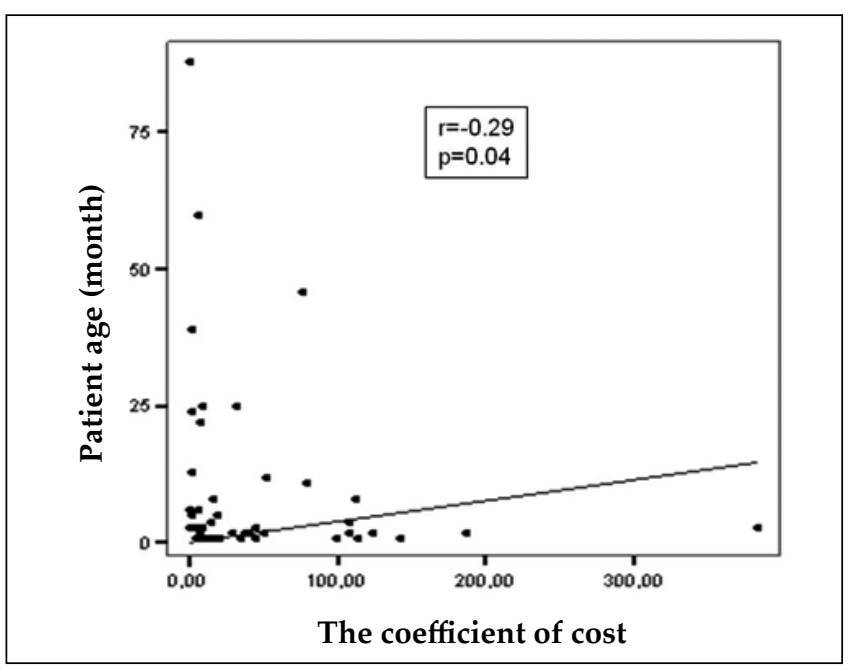

Figure 2: Correlation analysis between patient age and coefficient of cost.

infection. Aseptic conditions and the use of prophylactic systemic antibiotics have been proven to reduce the risk of shunt infection by half $(2,16)$. Antibiotic-impregnated shunt catheters have been used in many studies to reduce infection, but some studies have reported that they do not change the frequency of infection. Despite their additional cost of $\$ 400$ to 500 , they are used for shorter hospitalization periods as well as to reduce the likelihood of shunt infection by two-thirds. On the other hand, the type of shunt (adjustable, pressurecontrolled, or no-valve) was reportedly unimportant in terms of preventing infection in several studies $(1,8,9,14)$. The surgeon, surgical technique, operating room environment, and operation time were omitted from the analyses in this study. However, all patients received prophylactic antibiotic therapy after surgery. Antibiotic-impregnated catheters were not used in any patient; only a single type of shunt was used for all patients.

Several methods are used to treat shunt infections, including the use of systemic antibiotics in conjunction with the placement of a new shunt after an older one is removed, the use of systemic antibiotics with external drainage until the CSF is clear followed by the placement of a new shunt, and the use of antibiotics only. In this study, an external ventricular drain and systemic antibiotics were used in twothirds of all patients; the remaining patients were treated with antibiotics alone. These two treatment options did not affect the duration of hospitalization or the hospitalization and cost coefficients. None of the patients underwent removal of the infected shunt and direct shunt placement during the same session.

In the literature, the average cost of a shunt infection has been reported as 8 to 50,000 US dollars $(1,10,11)$. No studies have investigated the economic aspect of shunt infections in Turkey. We calculated an approximate cost of $5500 \mathrm{TL}$ for VPSI, and the cost per patient in the follow-up period was $\sim 13000$ TL. As expected, a younger age has been found to be 
negatively correlated with the cost of VPSI (cost coefficient). A review of cost analyses in foreign countries showed that the costs were much higher than those estimated in this study. One reason for this is the higher medical costs in countries other than Turkey (e.g., the standard bed and intensive care unit bed costs are 400 and 800 US dollars, respectively, in the USA, compared to 20 and 250 US dollars, respectively, in Turkey) (10).

In conclusion, the use of a VPS in the treatment of hydrocephalus is still considered to cause infection despite technological improvements and new measures. Our study is the first to evaluate the clinical and economical outcomes in children with VPSI in Turkey. Our results show that morbidity and medical costs in children are highly correlated with the presence of a medical history of premature birth and the age at first VPSI. The limitations of this study were its small sample size and single-center nature. Multi-center studies with larger sample sizes will contribute to the identification of VPSI risk factors and reduction of medical costs in Turkey.

\section{ACKNOWLEDGEMENT}

We thank Assoc. Prof. Nail Özdemir, MD, department of neurosurgery Izmir Tepecik Training and Research Hospital for his assistance with the collection of the data.

\section{REFERENCES}

1. Aryan HE, Meltzer HS, Park MS, Bennett RL, Jandial R, Levy ML: Initial experience with antibiotic-impregnated silicone catheter for shunting of cerebrospinal fluid in children. Childs Nerv Syst 21: 56-61, 2005

2. Bayston R, Bhundia C, Ashraf W: Hydromer-coated catheters to prevent shunt infection? J Neurosurg 102: 207-212, 2005

3. Borgbjerg BM, Gjerris F, Albeck MJ, Borgesen SE: Risk of infection after cerebrospinal fluid shunt: An analysis of 884 first-time shunts. Acta Neurochir (Wien) 136: 1-7, 1995

4. Braga MH, Carvalho GT, Brandao RA, Lima FB, Costa BS: Early shunt complications in 46 children with hydrocephalus. Arq Neuropsiquiatr 67: 273-237, 2009

5. Celik U, Alhan E: Cerebrospinal fluid shunt infections and treatment. Çocuk Enf Derg 3: 19-24, 2009

6. Choux M, Genitori L, Lang D, Lena G: Shunt implantation: Reducing the incidence of shunt infection. J Neurosurg 77: 875-880, 1992

7. Cochrane DD, Kestle JR: The influence of surgical operative experience on the duration of first ventriculoperitoneal shunt function and infection. Pediatr Neurosurg 38: 295-301, 2003

8. Eymann R, Chehab S, Strowitzki M, Steudel WI, Kiefer M: Clinical and economic consequences of antibiotic-impregnated cerebrospinal fluid shunt catheters. J Neurosurg Pediatr 1: 444-450, 2008

9. Eymann R, Steudel WI, Kiefer M: Infection rate with application of an antibiotic-impregnated catheter for shunt implantation in children - a retrospective analysis. Klin Padiatr 221: 69-73, 2009

10. Fobe JL, Rizzo AM, Silva IM, Da Silva SP, Teixeira CE, De Souza AM, Fernandes A:IQ in hydrocephalus and myelomeningocele.
Implications of medical treatment. Arq Neuropsiquiatr 57: 44-50, 1999

11. George R, Leibrock L, Epstein M: Long-term analysis of cerebrospinal fluid shunt infections. A 25-year experience. J Neurosurg 51: 804-811, 1979

12. Greenbeerg MS: Handbook of Neurosurgery. New York: Thieme Publications, 2010

13. Guzelbag E, Ersahin Y, Mutluer S: Cerebrospinal fluid shunt complications. Turk J Pediatr 39: 363-371, 1997

14. Kan P, Kestle J: Lack of efficacy of antibiotic-impregnated shunt systems in preventing shunt infections in children Childs Nerv Syst 23: 773-777, 2007

15. Kaufman BA: Infections of cerebrospinal fluid shunts. In: Scheld WM, Whitley RJ, Durack DT (eds), Infections of the Central Nervous System. 2nd ed. Philadelphia: Lippincott Raven, 1997:555-577

16. Khan I, Burhan M, Nadeem M: A reappraisal of contributing factors leading to shunt infection. J Ayub Med Coll Abbottabad 21: 66-68, 2009

17. Kontny U, Hofling B, Gutjahr P, Voth D, Schwarz M, Schmitt HJ: CSF shunt infections in children. Infection 21: 89-92, 1993

18. Kulkarni AV, Drake JM, Lamberti-Pasculli M: Cerebrospinal fluid shunt infection: A prospective study of risk factors. J Neurosurg 94: 195-201, 2001

19. Liptak GS, McDonald JV: Ventriculoperitoneal shunts in children: Factors affecting shunt survival. Pediatr Neurosci 12: 289-293, 1985

20. Odio C, McCracken GH Jr, Nelson JD: CSF shunt infections in pediatrics: A seven-year experience. Am J Dis Child 138: 1103-1108, 1984

21. Ratilal B, Costa J, Sampaio C: Antibiotic prophylaxis for surgical introduction of intracranial ventricular shunts. Cochrane Database Syst Rev 19: CD005365, 2006

22. Roos KL, van de Beek D: Bacterial meningitis. Handb Clin Neurol 96: 51-63, 2010

23. Telhan L, Cavusoglu F, Musluman M, Turkmenoglu O, Cetinkaya F: Etiologic and prognostic assessment of children with ventriculoperitoneal shunt infections. Çocuk Enf Derg 4: 100-103, 2010

24. The Ministry of Health of Turkey: Health Application Notification, Supplementary 8-9

25. Vinchon $M$, Dhellemmes $P$ : Cerebrospinal fluid shunt infection: Risk factors and long-term follow-up. Childs Nerv Syst 22: 692-697, 2006

26. Walters BC, Goumnerova L, Hoffman HJ, Hendrick EB, Humphreys RP, Levinton C: A randomized controlled trial of perioperative rifampin/trimethoprim in cerebrospinal fluid shunt surgery. Childs Nerv Syst 8: 253-257, 1992

27. Wang KW, Chang NW, Shih TY, Huang CR, Tsai NW, Chang CS, et al: Infection of cerebropinal fluid shunts: Causative pathogens, clinical features, and outcomes. Jpn J Infect Dis 57: 44-48, 2004 